\title{
Religiosity as a Mechanism to Control Delinquent Behaviour of School Students
}

\author{
Mohammad Ismath Ramzy ${ }^{1, * \mathbb{D}}$, Peer Mohamed Mohamed Irfan ${ }^{2}$ (D) and Zaharah Hussin ${ }^{1}$ (D) \\ 1 The Department of Educational Foundation and Humanities, Faculty of Education, University of Malaya, \\ Kuala Lumpur 50603, Malaysia; zaharah@um.edu.my \\ 2 Naleemiah Institute of Islamic Studies (NIIS), Beruwala 12070, Sri Lanka; irfan@naleemiah.edu.my \\ * Correspondence: ismathramzy@um.edu.my
}

check for updates

Citation: Ramzy, Mohammad Ismath, Peer Mohamed Mohamed Irfan, and Zaharah Hussin. 2021. Religiosity as a Mechanism to Control Delinquent Behaviour of School Students. Religions 12: 823. https:// doi.org/10.3390/rel12100823

Academic Editor: Lee Ross

Received: 28 July 2021

Accepted: 26 September 2021

Published: 1 October 2021

Publisher's Note: MDPI stays neutral with regard to jurisdictional claims in published maps and institutional affiliations.

Copyright: (c) 2021 by the authors. Licensee MDPI, Basel, Switzerland. This article is an open access article distributed under the terms and conditions of the Creative Commons Attribution (CC BY) license (https:// creativecommons.org/licenses/by/ $4.0 /)$.

\begin{abstract}
Delinquent behaviour among school students is a great concern of governments and educational institutions. Although the authorities and civil society organisations have tried to control the growing trend of school violence, antisocial behaviour among students is significantly increasing. The low delinquency rate among school students in Shah Alam, a city closed to the Malaysian capital, inspired the researchers to explore the association between religiosity and delinquent behaviour. The objective of this study is to explore the relationship between religiosity and the delinquent behaviour of school students. This research employed a mixed method to collect the data. An instrument consisting of 101 questions prepared based on the Muslim Religiosity-Personality Inventory (MRPI) was administrated to measure the level of religiosity. A total of 107 secondary school students (58 boys, 49 girls) aged 13 to 14 years participated in the data collection. A semi-structured interview was used to collect the data from four school counsellors and discipline teachers to examine the relationship between religiosity and delinquency. This research found a moderate level of religiosity among students in Shah Alam while having an inverse relationship between religiosity and delinquency. The researchers, therefore, recommend religiosity as a successful mechanism to control delinquency among school students.
\end{abstract}

Keywords: religiosity; Muslim Religiosity-Personality Inventory (MRPI); bullying; juvenile delinquency; school violence; antisocial behaviour

\section{Introduction}

School violence is a common phenomenon in modern society. People worldwide witnessed horrifying violence incidents among school students in their environment (Akiba et al. 2002). In contrast to common belief, school violence is not limited to developed countries and is a fact in developing countries (Benbenishty and Astor 2008). A UNICEF survey reports that 8 out of 10 students experience bullying in school (Education Destination Malaysia 2019). According to UNESCO, almost one in three students $(32 \%)$ has been bullied by their peers at school at least once in their school life (UNESCO 2019 , p. 7). A WHO report says that $43 \%$ of homicides out of 200,000 among youth age 10-29 are related to educational institutions (WHO 2020).

A similar situation is observed in Malaysia. The researchers found an increasing trend of delinquency among school students in the country (Pitts 2015). According to the Malaysian Home Ministry (MOHA), violent incidents among school students are increasing (Santhana and Rueben 2019). In 2012, 1047 criminal activities, including murder, gangsterism, rape, and armed robbery, were reported among Malaysian adolescents, while this number increased in 2013 by 2553 cases. Meanwhile, in 2013, the adolescent crime rate jumped by $26 \%$ in Penang (Brain 2013). This is further elaborated by the Malaysian Crime Prevention Foundation (MCPF) Vice-Chairman, who said that the students' involvement in crime in 2013 made up 1.1\% (1632 cases) of the total crime index in the country in 2012 (The Star 2014). The Malaysian Home Minister conveyed his worry over the increasing 
trend of school violence (El Sen 2014). The Malaysian Education Ministry report also confirmed the growing trend of violence among school students (Bernama 2014).

Although school violence slightly decreased in 2014 by 10.3\% (The Department of Statistics 2016, p. 2), it increased again from 2016 onwards. According to The Department of The Department of Statistics (2016), 4295 antisocial behavioural cases were reported in 2014; however, they increased to 4453 in 2015 (The Department of Statistics 2016, p. 2). The Malaysian Education Ministry report says 2968 bullying cases were recorded in 2015, while this number rose by 3448 in 2016 (New Strait Time 2019). This situation further worsened in 2017, and 5443 cases were reported (Department of Statistics Malaysia 2016). The Malaysian Education Ministry's report on 402 hotspot schools in August 2017 made people think about school violence seriously (Hashim et al. 2018). The United Nations International Children's Emergency Fund's global survey on school bullying endorsed this situation. It said that seven out of ten Malaysian children worried about being bullied at or around the school (New Strait Time 2019). The Department of Statistics Malaysia report in 2019 said that juvenile delinquency increased by 2.7\% in 2018 (Department of Statistics Malaysia 2019). Recent research on the crime index in Malaysia also highlighted this alarming situation (Hanif and Syariani Md 2020). These statistics show the increasing trend of school violence in Malaysia.

While delinquent behaviour among school students is increasing worldwide, including in Malaysia, surprisingly, Shah Alam, the capital city of Selangor, recorded a lower rate of delinquency among school students (Santhana and Rueben 2019). The Malaysian Ministry of Women, Family, and Community Development confirmed the lower crime rate in Shah Alam among school students (UNICEF 2013, p. 68). The statement of Shah Alam police chief described the recent crime trend in Shah Alam and confirmed a decrease of $22.6 \%$ crime trend in the city from 2014 to 2015 (Nabilah 2015). This is further elaborated in recent research on hotspot schools in Mukim Petaling and Klang. This study used the Location Quotient Crime (LQC) index to study 33 hotspot schools and found these hotspot schools in the study area contributed $10 \%$ of overall total crime. According to this report, there are four hotspot schools with LQC above 3.0. The crime occurs within buffer zones within 0-100 meters of these schools. These are SMK Tengku Idris Shah in Kapar, Klang (LQC of 5.1), which is a strong crime attraction, SMK Taman Medan in Petaling Jaya (LQC of 3.5), SMK Pusat Bandar Puchong (LQC of 3.3), and SMK Batu Unjur in Bandar Bukit Tinggi (LQC of 3.2). Among this list, none of the schools in Shah Alam were identified as a hotspot for crime (Hashim et al. 2018).

Shah Alam is a fast-growing and modernising city (Soh and Che 2012) that has had a high flow of internal migration from other states for decades (Rashid and Ghani 2011). This can increase criminal activities. However, the low rate of delinquent behaviour among school students in Shah Alam encouraged the researchers to look for associations between religiosity and low rate of delinquency for three reasons: (a) the city plan of Shah Alam, (b) sociologists views on the resilient connection between religion and violence, and (c) the use of religiosity by addiction scientists to control antisocial behaviour.

(a) Shah Alam City Plan

Islamic elements are incorporated in the Shah Alam city plan (Christina Low 2012), and people in Shah Alam are expected to be religious ((Hoffstaedter 2011, pp. 45-46). Mainly, Shah Alam has planned to motivate young people towards religiosity (Christina Low 2012). The researchers also have shown that people in Shah Alam prefer religiosity and consider Islam as their source of reference (Alam et al. 2011). Hence, the researchers were interested in exploring any association between religiosity and the low rate of delinquency in Shah Alam.

(b) Sociologists views on the resilient connection between religion and violence

Sociologists, in general, accept the resilient connection between religion and violence even though they have different opinions on the methodology. Functionalists consider religiosity as an appliance system to ensure peace and harmony in a society (Sonnenberg 2014), 
while conflict theorists perceive religiosity as an apparatus of elites to control the society (Al-Khalifah 1994).

Functionalists studied religion in the society based on Emile Durkheim's (1858-1917) analysis and concluded that religion was an effective mechanism to ensure social harmony in the society (Sonnenberg 2014). According to Emile Durkheim, the success of a society depends on the strength of individuals' integration into social institutions (Al-Khalifah 1994). Based on this view, social control theorists examined delinquent behaviour and crime. A group among them studied religion as a control mechanism focusing on society while other groups focused on individual psychology (Al-Khalifah 1994).

The first group highlighted the importance of religion in creating and maintaining the social order. According to them, religion imposes rules and legal regulations that control antisocial behaviour in society. Kunin (2003), for instance, considered that "religion should be seen as a means of social control, controlling individual emotional response and maintaining social order and cohesion" (p. 25). However, other groups studied religion focusing on individual consciousness. According to them, individual consciousness creates moral obligations in society (Güneş 2003, p. 43). Hence, according to functionalists, religion plays an essential role in controlling antisocial behaviour by imposing rules and regulations or creating moral consciousness.

For conflict theorists, religion is a mechanism for elites to control society. Therefore, Karl Marx (1818-1883) confirmed the role of religion in society and demonstrated his view in his analysis on the bourgeois and proletariat (Al-Khalifah 1994). According to him, the bourgeois used religion to maintain their dominance over the proletariat (Al-Khalifah 1994). Weber also discussed the influence of religion in controlling economic policies and described Protestant Christianity as a product of capitalism (Weber and Kalberg 2013, p. 18). Hence, according to conflict theorists, religion functions as a method of shaping individuals' behaviour in society.

In both cases, conflicts and functionalists, religion plays a significant role in moulding individual behaviours. Both of them confirmed the impact of religion on delinquent behaviour, even though they differ in explaining the sources and methodology. People learn appropriate behaviours in society through religious leaders' repeated elaboration (Ahmed 2009).

Hence, religions, according to sociologists, play a positive role in shaping the behaviour of people in society. Religions, therefore, control anti-behaviour and criminal activities. Neto (2007) highlighted this aspect and showed the role of religion in minimising hatred among people. Al-Khalifa, referring to Islam, argued for the role of religion in controlling violent attitudes in society. He said that Islam is stronger than other religions in this aspect (Al-Khalifah 1994).

Ramzy (2015) also studied the relationship between religiosity and violence among youths and found religiosity controlling violent behaviour (Ramzy 2015). He further explained that religiosity increases peace and internal harmony while regulating the behaviour of people by religious rules and regulations (Ramzy 2015).

\section{(c) The use of religiosity by addiction scientists to control antisocial behaviour}

Meanwhile, enough studies found religiosity to be an effective mechanism to control different kinds of addictions and antisocial behaviour (Sanchez and Nappo 2008). For instance, the addiction scientists recommended religiosity to control alcohol and drug addictions (Uba et al. 2014). It has been further elaborated in another study that religious education could minimise alcohol use, binge drinking, school underachievement, violence, and weapons possession (Isralowitz and Reznik 2015). A similar observation was found in Malaysia and confirmed the possibility of using religion as a controlling mechanism (Amini et al. 2014). The degree of religious commitments corresponds to one's behaviour (Usman 2015).

Hence, the Shah Alam city plan, the views of sociologists on the role of religion in society, and the use of religiosity by addiction scientists to control antisocial behaviour of 
alcoholic and drug addicts encouraged the researchers to study the low rate of delinquency in association with religion.

\section{Method}

This research is interested in exploring the relationship between religiosity and delinquent behaviour of school students in Shah Alam by asking the question: does religiosity control the delinquent behaviour of students in Shah Alam? This research question will be studied with two sub-questions: What is the level of religiosity among the students? Is there any significant relationship between religiosity and delinquent behaviour among students? To answer these questions, this research measured the level of religiosity of adolescents in Shah Alam by administrating a questionnaire while studying the association between religiosity and delinquency based on qualitative interviews. Hence, this research used a mixed method to collect the data and to proceed the study.

\subsection{Strategy of the Study}

Although some researchers argue that a person's religiosity cannot be empirically measured (Cassidy 2004), several measurement tools have been proposed by scholars to evaluate the level of religiosity. The definition of 'religion' is different from one religion to another (Al-Khalifah 1994), and scales to measure religiosity are also diverse.

Concerning measuring the religiosity of Muslims, many measurement tools are available such as the Behavioral Religiosity Scale (IBRS) (Othman 2011), Ummatic Personality Inventory (UPI) (Al-Ammar et al. 2012), Moral Character of Muslim Personality (MCMP) (Ismail and Tekke 2015), Integrative Islamic Personality Inventory (IIPI) (El-Menouar 2014), Five Dimensions of Muslim Religiosity (El-Menouar 2014), Psychological Measure of Islamic Religiousness (PMIR) (Abou-Youssef et al. 2011), and the Muslim Religiosity-Personality Inventory (MRPI) (Krauss et al. 2005). These measurement tools indicate the possibility of measuring the religiosity of Muslims based on the religious beliefs and their applications, such as rituals, ethics, and other variables.

Cultural differences are another essential aspect of religiosity scale. The religiosity of people within a religion needs to be considered cultural diversity. A scale prepared to measure the religiosity of Muslims in Pakistan might not be appropriate to measure the religiosity of Muslims in Sri Lanka. For instance, the scale of Suhail and Chaudhry (2004) to evaluate the religiosity of Muslims in Pakistan is different from the religiosity scale of Abdel-Khalek in Kuwait (Tiliouine et al. 2009). Although both of them were prepared to evaluate the religiosity of Muslims, the items in both of these scales are different due to the differences in culture.

As this research studies the religiosity of Muslims in Malaysia, the researchers preferred to use the Muslim Religiosity-Personality Inventory (MRPI) scale as it is developed to evaluate the religiosity of Muslims based on Malaysian participants. MRPI consists of two dimensions, the Islamic worldview and religious personality (Krauss et al. 2005). The Islamic worldview reflects the Tawhidic paradigm or divine unity. This dimension is constructed based on an Islamic belief system (Aqidah) that demonstrates one's level of agreement with the statements related to pillars of faith (Arkan-al-Iman), namely belief in God, belief in angels, belief in revealed books, belief in messengers, belief in destiny, and belief in retribution (Krauss et al. 2005). The religious personality aspect of MRPI is constructed based on Ahlaq (Islamic ethics), Ibadat (Rituals), and Mu'amalat (Social Relations) (Krauss et al. 2005). Ahlaq-Islamic Ethics is the manifestation of the Islamic worldview. This includes behaviours, motivations, attitudes, and emotions related to one's neighbours, family, co-religionists, and others (Krauss et al. 2005). Ibadat (Rituals) is the aspect that represents the human relationship with God expressed through ritualistic acts such as prayer, fasting, reading Qur'an, charity, and others (Krauss et al. 2005). Mu'amalat (Social Relations) is a human relationship with others, including fellow human beings and creations (Krauss et al. 2005). Since Islamic ethics are guided by Islamic religious teaching and God-consciousness (Taqwa) (Krauss et al. 2005), this measurement tool includes the 
spirituality of Islam. Hence, this research did not evaluate the spirituality of Muslims separately.

The level of religiosity among students in Shah Alam will be measured in this research based on the MRPI tool. Qualitative interviews will examine the relationship between religiosity and delinquency. The interview questions were prepared based on the MRPI tool, allowing the participants to share their experiences with school students. The conceptual framework of this research, therefore, is as follows:

Figure 1 explains the association between Islamic religiosity and the delinquent behaviour of adolescents. The level of religiosity in this diagram will be determined from the perspectives of Aqidah (worldview), Ahlaq (ethics and morals), Ibadat (rituals), and Muamlat (social relationship). According to this diagram, religiosity and delinquent behaviour have an inverse relationship, and the religiosity of a person will decrease the delinquent behaviour.

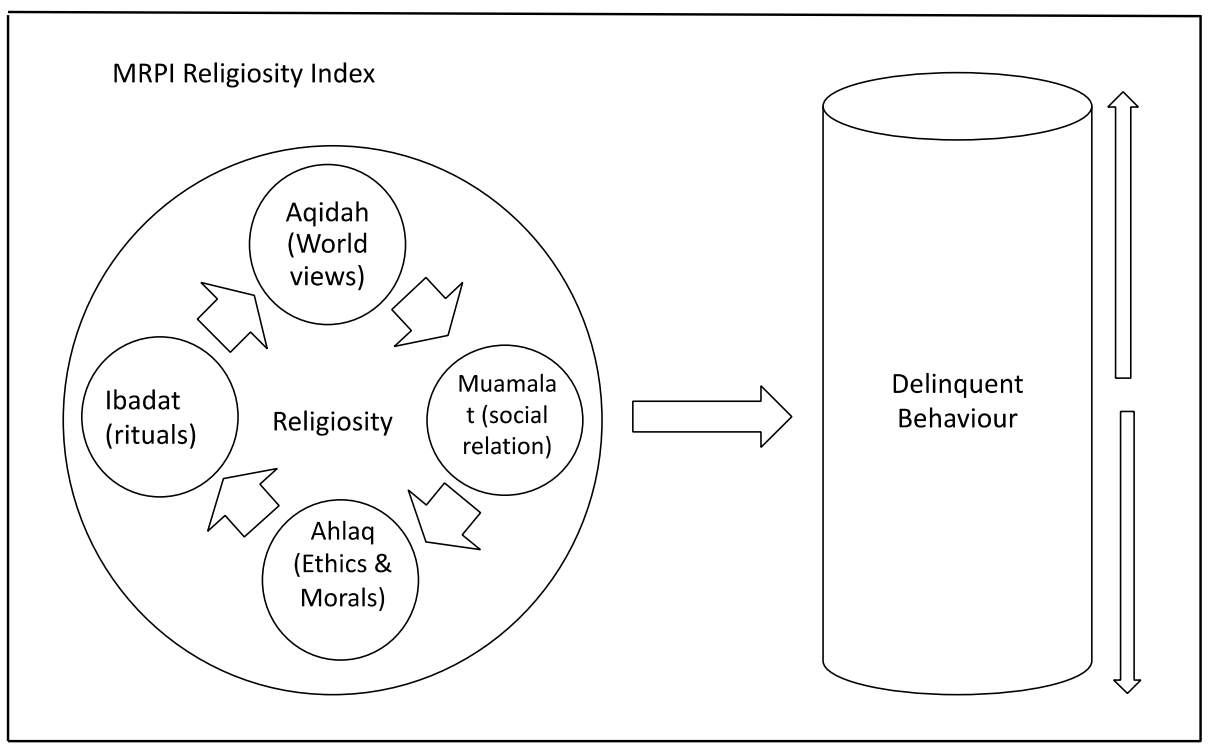

Figure 1. The association between Islamic religiosity and delinquent behaviour.

\subsection{The Sample}

This research used a mixed-mode method to study the research question, and data were collected from quantitative and qualitative methods. A cross-sectional study was conducted to understand the level of religiosity in four schools in Shah Alam from July to November 2019. A total of 107 secondary school Muslim students (58 boys and 49 girls) aged 13 to 14 years participated in this data collection. The respondents, all with discipline problems, were identified with the help of discipline teachers and counsellors based on their disciplinary merit system. Every student is given 100 points at the beginning of the year, and any disciplinary action will reduce these points (Epic Teachers 2013). The schools involved in this research maintain the disciplines that ensure punctuality, respecting teachers and others, irresponsible behaviour, and other school rules. The objective of this data collection was to evaluate the level of religiosity among these students.

The relationship between religiosity and delinquent behaviour among students was studied based on the qualitative data collected from student counsellors and discipline teachers who are currently working in the same schools. An intensive method was used to collect data using semi-structured questions. Each interview was conducted online due to the COVID-19 situation for around 30 minutes. The participants shared their experience dealing with the students who participated in the quantitative data collection and explained their social and antisocial behaviour observations. (See Table 1). 
Table 1. Participants in qualitative data collection.

\begin{tabular}{ccccc}
\hline No. & Designation & ID & Experience in Years & Gender \\
\hline 1 & Discipline teacher & $\mathrm{DT}_{1}$ & 15 & Male \\
2 & Discipline teacher & $\mathrm{DT}_{2}$ & 10 & Male \\
3 & Discipline teacher & $\mathrm{DT}_{3}$ & 03 & Male \\
4 & Student counsellor & $\mathrm{SC}_{1}$ & 10 & Female \\
\hline
\end{tabular}

\subsection{The Instruments and Techniques Used in This Study}

A survey instrument prepared based on MRPI (Krauss et al. 2005) was implemented in this research. The Muslim Religiosity and Personality Inventory (MRPI) is an Islamic religiosity measurement developed for Muslims in Malaysia (Krauss et al. 2005). This study uses the full version of the questionnaire. It has two subscales, namely Islamic Worldview, with 23 items, and Religious Personality, with 78 items. Islamic Worldview is rated on a five-point scale from 1 (strongly disagree) to 5 (strongly agree). Higher scores on this subscale represent more excellent knowledge and perceptions towards Arkan-al Iman, the pillars of the belief system: belief in Allah (the creator), belief in angels, belief in retributions (day of judgement) (existence/transcendence), and belief in revealed books and messengers (all-encompassing religion).

Religious Personality is rated on a five-point scale ranging from 1 (never) to 5 (always). Higher scores on this subscale represent the more incredible practice of Islamic obligations. The practical expression of religion is studied in this instrument from three perspectives: Ahlaq (self), Ibadat (rituals), and Muamalat (social). A scoring table provides the norm score to measure high or low scores for the two subscales relative to the population. The MRPI has been highly valid and reliable among Malaysian Muslims, with item analysis at an alpha value of 0.91 (Krauss et al. 2007).

Since all scales were readily available in English, all measuring items were translated and adapted in Malay for local administration. For this purpose, forward and backward translations were performed by experts and linguists from University Malaya. In brief, the results of the translation process were exemplary. The translated version showed good consistency with the original English version. The final version of PSAB-J was subjected to other validity and reliability tests. However, the interview was conducted in English for the qualitative data collection method as the student counsellors and disciplinary teachers communicated in English.

The validity of instruments was made by using content-related evidence of fact by expert judgment or intelligent judgment such as that proposed by Fraenkel et al. (2012); Wiersma and Jurs (2000); and Cohen et al. (2000) to prove the accuracy of the content item. Thus, researchers used four experts in 'religiosity' to make the grinding accuracy of the instrument's content: two experts from the Academy of Islamic Studies and two other people from the Faculty of Islamic Education.

The concept of measurement reliability in quantitative methods, especially the use of questionnaires by Russell and Pratt (1980), is designed to test a different set of questions (questionnaire) through a review/test pilot (pilot test). Borg et al. (1979) explain that the pilot test aims to ensure data transparency by demonstrating the question in a small group. Another objective, as stated by Roid and Haladyna (1982), is evaluating the item's consistency (reliability): item-level, the objective item, item understanding, usability items, and the command item itself.

\subsection{Procedure}

The following paragraph explains the procedure used to carry out this study. The researchers have used $n=30$ samples in a pilot test as proposed by Gorsuch (1983), McDermott and Sarvela (1999), and Hair et al. (2019) through the technique of test-retest reliability. The results of the pilot test showed the Cronbach alpha value of 101 items is $\mathrm{a}=0.814$. According to Vierra and Pollock (1992), it is acceptable reliability. Previously, 
Nunnally (1978) also said that the coefficient alpha correlation coefficient or Cronbach alpha must exceed 0.70 to be considered reasonable.

For the study, the researchers first obtained written permission from the Educational Planning and Research Department (EPRD) of the Ministry of Education, Malaysia. Later, the researchers sought written permission from the State Education Department to collect data from schools. With the authorities' approval, the researchers approached the administrator of the schools to coordinate the data collection. The participants were informed about this research, and the school authority obtained permission from the parents before the data collection. The researchers arranged to come on the day that had been fixed for the survey. The survey took two days. Researchers approached the disciplinary teachers and school counsellors of the same schools to understand the relationship between religiosity and delinquent behaviour. They arranged the date and time to conduct the interview online due to the COVID-19 situation.

\subsection{Analysis of Data}

The collected data were computed and analysed using the IBM Statistical Package for Social Sciences (SPSS) version 20.0. The respondents' demographic information was analysed using descriptive statistics to summarise the respondents' backgrounds. The demographic groupings were also used for comparison purposes in subsequent analysis. The findings for each scale were reported in mean scores to identify the level of religiosity among the participants.

Data triangulation is necessary to comprehensively understand the live experience in qualitative data collection (Patton 1999). Hence, this research involves the triangulation method as it uses different forms of data collection for the same purpose, such as interviews, video recording, and students' feedback (Patton 1999). The participants were informed about the purpose of the data collection, and their consent was obtained before the interview. They also were assured confidentiality.

Regarding the qualitative interviews, Semi-structured questions were used to collect the data from four school counsellors and discipline teachers to examine the relationship between religiosity and delinquency (Small 2011). Since transcribing data is the fundamental component in qualitative research (Davidson 2009), all the interviews were transcribed. To ensure the authenticity of data, researchers sent the drafted interviews to the participants before coding and analysing. The collected data were coded and analysed. Before the interview, the questions were sent to the participants, who were given enough time to prepare the answers to ensure their freedom to express their opinion (Malaysian Education Blueprint 2015). The data were coded based on the Gibbs (2007) model using the deductive coding method (Christians and Carey 1989). The researchers read the coded data many times and developed themes (Vaismoradi and Snelgrove 2019). Since this research explores the live experience of student counsellors and disciplinary teachers, it used Moustakas (1994) systematic data analysis as it allows researchers to develop an objective essence through subjective experiences (Moustakas 1994, p. 22). This method was helpful for the researchers to understand the association between religiosity and delinquency.

\section{Findings}

This research investigated the association between religiosity and antisocial behaviour by asking whether religiosity controls adolescents' delinquent behaviour. The data collected from school students, students' counsellors, and discipline teachers in Shah Alam were analysed. The findings of this analysis are discussed under two themes: the level of religiosity among school students and the association between religiosity and delinquency.

\subsection{The Level of Religiosity among Students}

This section of findings shows the level of religiosity among students in Shah Alam and the socio-economic analysis of the data. This section discusses two sub-themes: (i) the level of religiosity and (ii) socio-economic analysis of the data. 


\section{(i). The level of religiosity}

This research evaluated students' religiosity in Shah Alam based on the MRPI instrument. The finding of this part is presented based on following the criteria shown in Table 2.

Table 2. Analysing criteria.

\begin{tabular}{cc}
\hline Interval Mean & Interpretation \\
\hline $1.00-2.33$ & Low \\
$2.34-3.67$ & Moderate \\
$3.68-5.00$ & High \\
\hline
\end{tabular}

As standard deviation is commonly used in reporting descriptive statistics for continuous data (Fisher and Marshall 2009), this research used standard deviation to describe the range of religiosity among students in Shah Alam. Accordingly, as shown in this table, mean value 1.00-2.33 has been interpreted as low, mean 2.34-3.67 has been interpreted as moderate, and mean 3.68-5.00 interpreted as high in religiosity. Table 3 indicates the summary of this analysis as well as its interpretations.

Table 3. Descriptive analysis of religiosity.

\begin{tabular}{cccc}
\hline Dimension & Mean & SD & Interpretation \\
\hline Aqidah (worldview) & 3.51 & 1.4 & Moderate \\
Ahlaq (ethics and morals) & 3.45 & 1.3 & Moderate \\
Ibadat (rituals) & 3.41 & 1.2 & Moderate \\
Muammar (social relationship) & 3.52 & 1.2 & Moderate \\
Overall & 3.47 & 1.3 & Moderate \\
\hline
\end{tabular}

Referring to Table 3, the overall mean of descriptive analysis of data is 3.47. As far as interval means is $2.34-3.67$, the overall religiosity of participants in this research is moderate. It has further elaborated from the perspectives of Aqidah (worldview), Ahlaq (ethics and morals), Ibadat (rituals), and Muamlat (social relationship) as follows.

Aqidah-Islamic worldview: According to Table 3, the students who participated in this research are moderately religious from the perspective of Aqidah-Islamic worldview since the mean is 3.51. This aspect of religiosity was studied from students' knowledge in pillars of Islamic beliefs (Arkan-al-Iman), namely, belief in God, belief in angels, belief in revealed books, belief in messengers, belief in destiny, and belief in retribution.

Ahlaq or ethics and morals: Ahlaq or ethics and morals is an aspect of religiosity. This aspect studied one's relationship with God based on personal striving. Referring to Table 3, this research found a 3.45 mean in the analysis representing the intermediate state of religiosity among students in Shah Alam.

Ibadat (rituals): This aspect also is another aspect of practical religiosity. As shown in Table 3, this research found a 3.41 mean in Ibadat among students in Shah Alam. Ibadat reflects one's direct relationship with Allah through ritualistic acts such as prayer, fasting, reading Qur'an, charity, and others.

Muammar (social relationship) or interpersonal-interactive: this is another aspect of religiosity in Islam. The statements related to one's social connection, including family, neighbours, co-workers, co-religionists, and others, are used to evaluate religiosity from this aspect. Table 3 shows that this research found a 3.52 mean of religiosity in Muamalat. Hence, data analysis to measure the religiosity among students in Shah Alam from the perspective of Aqidah or worldview, Ahlaq or ethics, Ibadat or rituals, and Muamalat or social relationship moderately confirmed the moderate state of religiosity among students in Shah Alam. 


\section{(ii). Socio-economic reasons and delinquency}

According to the analysis, $54.2 \%$ of the participants in this research were male, while only $45.8 \%$ were female. Although there is not a significant difference between gender in this research, the number of male participants is 58 out of 107. Regarding the age, all participants in this research were adolescents, $57.9 \%$ of them were 13 years old, and the rest were 14 years old.

Regarding location, $82.2 \%$ of students who participated in this study live in urban areas, while only $17.8 \%$ live in rural areas. Further, this analysis also showed that the majority of students (57\%) who participated in this survey were from low-income families as their parents earn RM1000 (USD 240)-2000 (USD 480) monthly compared to $35.5 \%$ of students whose family income is between RM3000 (USD 720)-4000 (USD 960). Only 7.5\% of students who participated in this survey were from high-income families.

The majority ( $45.8 \%)$ of students' parents in this research were not much educated, and they had only qualified at a SPM level of education, while $33.6 \%$ of students' parents studied at an advanced level. Only $15.0 \%$ of them had a diploma level of education, while $5.6 \%$ had a degree in specific fields.

Parents' social status is another reason that increases delinquent behaviour among their children. According to the data analysis, $54.2 \%$ of students' parents in this survey were middle class, while $39.3 \%$ were lower. Only a few students representing $6.5 \%$ in this survey were upper-middle class.

\subsection{Religiosity Anddelinquency among Students}

The qualitative data analysis on the relationship between religiosity and delinquent behaviour among students in Shah Alam is presented under this theme. All the participants in this analysis confirmed that the students in Shah Alam have no record of criminal activities, although they have issues related to antisocial behaviour.

Figure 2 explains common antisocial issues among students in Shah Alam. According to this figure, bullying and dishonesty are very high among them, while vandalism, cheating in exams or assignments, and other minor issues are common. However, according to this figure, no school counsellors and discipline teachers came across any record of criminal activities such as drug abuse or sexual misbehaviour. The detailed report of the qualitative data analysis has categorised under four sub-themes, namely Aqidah or worldview and delinquency, Ahlaq or ethics and delinquency, Ibadat or rituals and delinquency, and Muamalat or social relationship and delinquency.

What kind of anti social behaviour is common among school students:

$0 / 4$ correct responses

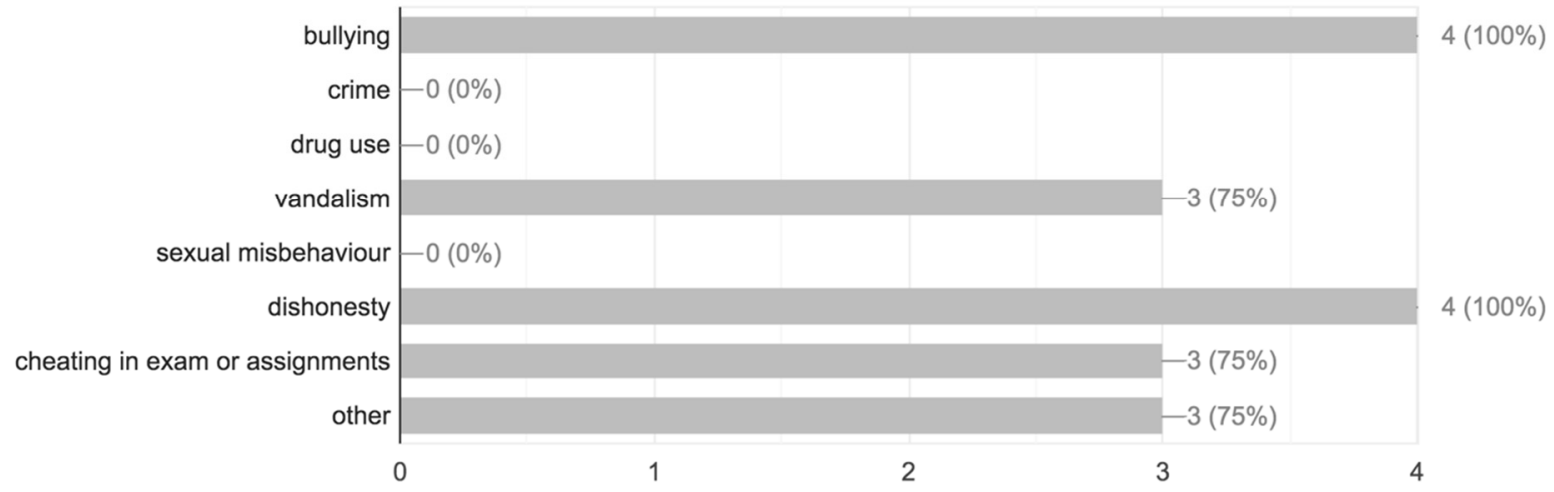

Figure 2. Common antisocial Issues among students in Shah Alam. 


\section{(i). Aqidah or worldview and delinquency}

The qualitative data analysis in this research found only little chance for the religious students in terms of Aqidah to be involved in criminal activities. The student counsellor said, "we usually remind students of the existence of God and His presence everywhere. So, we say them that their activities are informed to Allah although they might hide to us" ( $\mathrm{SC}_{1}$-032-034). It means God-consciousness has been used by the school administration to manage delinquent behaviour. However, the prevalence of issues such as bullying, dishonesty, and other minor problems were justified based on students' weakness in Godconsciousness or their absentmindedness. A disciplinary teacher said, "students were involved in bullying, physically or verbally or sometimes through social media. When we reminded them of Allah, they realised their mistakes" ( $\left.\mathrm{DT}_{3}-055-056\right)$. It shows the students forget themselves and lose God-consciousness when they are involved in bullying or other irresponsible activities. They all agreed although the students who have a minimum level of knowledge and commitment in the Islamic worldview were hardly involved in any criminal activities. Another discipline teacher explained it and said, "I hardly come across any criminal cases like sexual misbehaviour or drug abuse from a student who has feared for Allah" ( $\left.\mathrm{DT}_{2}-098-102\right)$. Hence, the students who have God-consciousness are hardly involved in any criminal activities, even if they are involved in minor social issues.

(ii). Ahlaq or ethics and delinquency

Ahlaq-Ethics is another aspect of religiosity. Data analysis of this research found that the religious students in Ahlaq were hardly involved in criminal activities. The student counsellor responded to a question on students who come to her for counselling, "if they are good enough in Ahlaq, why they should come for counselling" ( $\left.\mathrm{SC}_{1}-155-157\right)$. It shows that only the students who are not religious in terms of Ahlaq come for counselling. A disciplined teacher said, "the students who admonish others from wrongdoing are hardly involved in antisocial activities, perhaps they might avoid it to maintain their name among their peers or might avoid for fear for Allah" (DT2-170-172). It shows that the students who advocate good and admonish bad things will not be involved in antisocial activities whatever their motivation, fear for Allah or fear for their name, among others.

\section{(iii). Ibadat or rituals and delinquency}

The majority of participants in qualitative data collection said that the religious students in terms of Ibadat, such as praying Solat on time and other rituals, are generally not involved in criminal activities. The student counsellor, for instance, said, "I have experience in dealing with students for more than ten years, and I found the students who regularly pray Solat are hardly involved in criminal activities. However, they sometimes lie among friends for joking or use rude words in their conversation" (SC 1 -272-274). It means the religious students will not be involved in criminal activities such as drug abuse, murder, or others, although they commit antisocial activities such as bullying. A disciplined teacher's statement elaborated and said, "I could do not remember any student who prayed Solat on time with us in the prayer hall involved in criminal activities. They sometimes were caught for cheating in exams or bullying. They regret even if they are involved in these issues" $\left(\mathrm{DT}_{1}-320-321\right)$. It means the religious students in terms of Ibadat are hardly involved in criminal activities, but sometimes they commit antisocial behaviour. Another discipline teacher further endorsed this view. He answered a question on the reaction of students who are religious in Ibadat to scolding: "they may not get angry if someone scolds them; however, they will not remain silent when someone insults their parents or religion or race" $\left(\mathrm{DT}_{2}\right.$-380-382). It shows that religious students in terms of Ibadat will refrain from criminal activities, although they sometimes are involved in minor antisocial behaviours such as using rude words.

(iv). Muamalat or social relationship and delinquency

The relationship between the Muamalat aspect of religiosity and delinquent behaviour of students was studied based on the qualitative analysis. The participants were asked about their experience and opinion about the students who use lessons from the Qur'an 
and Hadith in their conversations, follow Islamic dress code in daily life, and have financial and other dealings according to Islamic teaching, and whether they have any complaint against them. All participants in this research said that they hardly receive a complaint against these students. Regarding the dress code and social dealings, the student counsellor said, "From my experience, I can tell you that the students who follow Islamic dress code sometimes are naughty but not criminal. However, I hardly get a complaint about the social dealing of these students" (SC 1 -403-406). A discipline teacher's statement supports this view and says, "the students who practice social relationship according to Islam will not offend others, even their causal conversation of joking around with others" $\left(\mathrm{DT}_{3}-430\right.$ 432). However, another discipline teacher disagreed with this opinion. He said, "these students sometimes hurt others in their conversation, and I get a complaint against them. Particularly, they hurt those who do not practice daily prayers or fasting in Ramadan" $\left(\mathrm{DT}_{1}-460-461\right)$. A total of $75 \%$ of participants in this research supported this view. Another discipline teacher said he had experienced a student who had cut off his relationship with his friends due to verbal bullying $\left(\mathrm{DT}_{2}-490-492\right)$. Hence, religiosity in Muamalat also influences delinquent behaviour.

\section{Discussion}

This section discusses the data analysis finding of this research. This study found a moderate level of religiosity among students in Shah Alam as well as an inverse relationship between religiosity and delinquency. These findings are discussed under two themes: (i) delinquency and socio-economic reasons and (ii) delinquency and religiosity. Each theme of this section consists of sub-themes. The first theme, 'the delinquency and socioeconomic reasons', has sub-themes such as gender differences, parents' income, educational level, social status, and urbanisation. The second theme, 'the delinquency and religiosity', has four subthemes: Aqidah, Ahlaq, Ibadat, and Muamalat.

\subsection{The Adolescents' Delinquency Rate and Socio-Economic Reasons}

Studies found that socio-economic reasons such as family background (Aute et al. (2020)), place of residence (Zhang (2016)), parents' education level (Chalfin and Deza (2019)), household income (Berti and Pivetti (2019)), gender (Kim 2021), and urbanisation (Wahab et al. (2018)) are some contributing factors to the delinquent behaviour of adolescents. Hence, the delinquency rate among students in Shah Alam in this section is studied from socio-economic reasons under the following sub-themes: gender differences, parents' income, parents' educational level, parents' social status, and urbanisation.

(i). Gender Differences:

The number of male participants is more than the number of females in this research. Male participants represent $54.2 \%$, while only $45.8 \%$ are females. Referring to previous studies, boys are more vulnerable to delinquency than girls. Herrera and McCloskey (2001) and Moffitt et al. (2001) found boys tend to show higher delinquency levels than their female peers. A meta-analysis of Card et al. (2008) also suggested the same. Recent research by Kim (2021) confirmed the prevalence of higher delinquency among males than females. Hence, the delinquent rate among students in Shah Alam could be expected to be higher than the present as most of them were male. However, this research found otherwise. Therefore, gender could not be a reason to explain the low rate of delinquent behaviour among students in Shah Alam.

\section{(ii). Parents' income:}

This research found the students in Shah Alam are not economically well-off. A total of $57 \%$ of them come from low-income families. Their parents only earn RM1000 (USD 240)2000 (USD 480) monthly, while only 7.5\% of them come from high-income families. Berti and Pivetti (2019) discussed the connection between economic disadvantage and antisocial behaviour and said that poverty leads to social misconduct and crimes. Browman et al. (2019) also have similar findings. As parents' poor economic condition is an important 
reason for delinquent behaviour among adolescents (Oshako 1997), students in Shah Alam are inclined to delinquent behaviour than others. Referring to their parents' economic condition, the students in Shah Alam are vulnerable to delinquency. Hence, the low rate of violence among them could not be explained based on their economic condition.

\section{(iii). Parents' Education Level:}

Although the participants' parents are not much educated, and most of them only have an SPM (the equivalent to GSCE in England or GCE O/L in the commonwealth of Nations) level of education, these students have a low level of delinquency. According to data analysis, only $33.6 \%$ of students' parents have studied at the advanced level while $15 \%$ have a diploma. Only $5.6 \%$ of them have a degree in a specific field. It shows the participants' parents in this research are less educated. Indeed, studies found the low level of parents' education is a cause of delinquency. Chalfin and Deza (2019) discovered a significant correlation between parents' level of education and delinquent behaviour among school students. According to them, the low level of parent's education contributes to the high level of delinquency (Chalfin and Deza 2019). Since the low level of parents' education has been identified as a reason for the delinquent behaviour of school students, it cannot be a reason to explain the low rate of delinquency among students in Shah Alam.

(iv). Parents' social status:

Referring to the finding of this research, $54.2 \%$ of students' social status is middle class while $39.3 \%$ of them were lower-middle class. Only a few students' social statuses, representing $6.5 \%$, are upper-middle class. Hence, $93.5 \%$ of students' status is lower or middle class. Studies found the parents' societal status is an important reason for students' delinquent behaviour. For instance, Nye et al. (1958) found a significant connection between social status and delinquent behaviour among students. Synder and Patterson (1987) also identified social status as an imperative factor among five themes in the literature that contribute to the errant behaviour of students. Daly's (1989) findings also proved the link between social status and delinquent behaviour. In their systematic literature review, Wright and Wright (1992) elaborated on the relationship between social status and delinquency. Aute et al. (2020) found that the parents' status affects virtually all aspects of children's lives, including the physical, emotional, mental, and parental environment. As the majority of students' parents' social status is lower than the middle class, the low rate of delinquency among them could not be justified for this reason.

(v). Urbanisation:

Urbanisation is another critical factor that promotes violence among adolescents. Ferdoos and Ashiq (2015), for example, found urbanisation as a cause of violence among school students. Zhang (2016) further elaborated on this aspect and explained how urbanisation could contribute to violence. Malaysian researchers also testified the influence of urbanisation on delinquent behaviour of adolescence and described it as a primary contributing factor for the high rate of violence in Selangor (Wahab et al. 2018). This research confirmed that $82.2 \%$ of students who participated in this study live in urban areas, while only $17.8 \%$ live in rural areas. Hence, the low rate of violence among school students in Shah Alam cannot be explained based on urbanisation.

The discussion above found that Shah Alam is vulnerable to developing delinquent behaviour among students. However, the low rate of delinquency among school students in Shah Alam cannot be justified by any socio-economic reasons.

\subsection{Religiosity and Adolescents' Delinquency}

From the above discussion, it is found that socio-economic reasons are insufficient to explain the low crime rate among school students in Shah Alam. The data analysis in this research supported sociologists (Al-Khalifah 1994) and addiction scientists (Sanchez and Nappo 2008) finding of an inversive relationship between religion and delinquent behaviour. Hence, this research argues for religiosity as an option to justify the low rate of delinquency among students in Shah Alam. This is discussed under four subthemes: 
Aqidah or worldview and delinquency, Ahlaq or ethics and delinquency, Ibadat or rituals and delinquency, and Muamalat or social relationship and delinquency.

(i). Aqidah or worldview and delinquency

The descriptive analysis in this research found a moderate Islamic worldview among students in Shah Alam. The qualitative data analysis highlighted the lower chance for religious people in Aqidah to be involved in criminal activities. Knowledge of Allah as the creator and omnipresence and belief in other articles such as retribution and revealed books, angels, and predestination created God-consciousness among them. The Quran said, "He knows all that is before them and all that is behind them" (Q 2.55). It means every action of a human being is observed and recorded. Another verse in the Quran explains it in detail, "Whether you speak aloud [or in a low voice], He hears all, for He knows your secrets and what is even more hidden ( $Q$ 20:07). Hence, these verses of the Quran state that Allah knows what you think, what you do, your plans, and what you say to yourself (Alghamdi 2006). In other words, the Islamic worldview creates consciousness regarding God's knowledge of human activities that prevent a person from being involved in criminal activities.

As consciousness on surveillance is a strong social force that affects human emotions, impressions, values, and ultimately behaviour according to the social impact theory of Latane (Jansen et al. 2018), religiosity in terms of Aqidah creates a spiritual-based controlling mechanism of social behaviour. Indeed, criminologists today use surveillance cameras to monitor criminal activities such as vandalism and theft based on this theory (Jansen et al. 2018). Hence, a spiritual-based social force might have helped the students in Shah Alam not to be involved in criminal activities.

\section{(ii). Ahlaq or ethics and delinquency}

The moderate level of religiosity in terms of Ahlaq-Islamic ethics among students in Shah Alam is another finding of this research. The students' counsellor and discipline teachers agreed that the moderately religious students in terms of ethics would not be involved in criminal activities. As far as encouraging good and admonishing wrongdoing is Islam's basic ethics (Ramzy et al. 2020), the person who advocates good and criticises wrong will not be involved in antisocial behaviour. Al-Ghazzali also said that the person who supports praiseworthy actions would not be involved in criminal activities (Muhammad 1983, p. 22).

Hence, Ahlaq, primarily advocating good and admonishing wrongdoing, creates psychosocial forces based on Islamic teachings that control a person's involvement in criminal activities. Neuroscientist Newberg (2016) said that a person's relationship with God stimulates their emotional processing areas in the neuron system and encourages practising forgiveness, compassion, empathy, and charity. Hence, religiosity in terms of Ahlaq, according to this finding, is a force to control delinquent behaviour and is the method to increase praiseworthy actions such as forgiveness, compassion, and empathy. Neuroscientists also highlighted it further and said that long-term compassionate communication and contemplative practices reinforce a specific neurological circuit that generates peacefulness and solitude, followed by positive wellbeing (Newberg and Waldman 2013, p. 26). Therefore, religiosity in terms of Ahlaq might have influenced the delinquent behaviour of students in Shah Alam.

\section{(iii). Ibadat or rituals and delinquency}

This research found that the students in Shah Alam had moderate religiosity from the perspective of Ibadat. On the other hand, the qualitative analysis of students' counsellors and discipline teachers confirmed that the students who practice rituals moderately would not be involved in criminal activities. However, they sometimes were involved in minor antisocial issues. The Ibadat such as Solat (prayer), Zakat (compulsory tax), Sawm (fasting), Haj (pilgrimage), Tilawat (recitation of the Quran), Dua (supplication), Dhikr (remembering Allah), and Sadaqa (giving away) generally promote social behaviour and disciplines. Solat (prayer), for instance, is a way of disciplining human social behaviour. The Quran said, 
"surely prayer restrains one from indecency and evil and remembrance of God is greater. God has knowledge of all your actions" (Q 29:45). Researchers found similar observations in the Quran for Zakat (Q 9:103), fasting (Q 2:183), haj (Q 2:197), and other rituals (Q 2:177). Hence, ritualistic religiosity in Islam shapes human behaviour and change human attitudes.

According to Marshall (2002), ritualistic religiosity generally generates belongingness to society by activating multiple social-psychological mechanisms. He further said that the distinctive elements of ritual practice induce subjective states and anomalous behaviours (Marshall 2002). The connection between ritualistic religiosity and antisocial behaviour is further elaborated by psychosocial analysis. Payne et al. (1991) studied how religious rituals relate to mental disorders. In this study, this research team highlighted the positive relationship between religiosity and social behaviour, particularly in personal adjustment and social conduct, while emphasising the role of religiosity in controlling alcohol and drug abuse and sexual permissiveness and suicide (Payne et al. 1991).

A group of neurologists underlined the relationship between the ritualistic religiosity of Islam and social behaviour. Newberg et al. (2015) studied the benefit of Solat in controlling human behaviour. They found that Solat (prayer) substantially impacts psychological and cognitive processes related to human behaviour. This team investigated this impact from an intrinsic (self-motivated) perspective (Newberg et al. 2015). Intrinsic motivation motivates a person to carry out religious rituals seriously and adjust their needs and wishes according to the religious guidelines. Hence, in terms of rituals, the religious person will consider their needs less important than religious teaching (Aisyah 2016). Thus, the ritualistic religiosity in Islam might have discouraged students in Shah Alam from being involved in delinquent behaviour. Further, self-motivated values gained through ritualistic practices might have helped them adjust their emotions based on the guideline of religion.

(iv). Muamalat or social relationship and delinquency

Muamalat is a necessary aspect of religiosity in Islam. In this research, qualitative data analysis from student counsellors and discipline teachers revealed that the Muamalat perspective's religiosity and delinquency have an inversive relationship. As Muamalat is the aspect of religiosity that expresses the knowledge and commitment of religion in social relations (Kamaruddin and MdAuzair 2019), this aspect of religiosity is directly connected to people's behaviour. Halal or cheating-free dealings (Ali et al. 2017), an interest-free economy (Rashidiyaan et al. 2018), as well as peaceful relations with others (Dastagir and Ramzy 2019) are some of the examples of Muamalat.

Hence, religiosity from the perspective of Muamalat ideally discourages delinquent behaviour and antisocial issues. It is further elaborated in research investigating the relationship between religiosity and consumer behaviour (Aisyah 2016). According to this research, the person who is obedient to the God from the perspective of Muamalat will have praiseworthy social activities (Aisyah 2016). Hence, the Muamalat aspect of religiosity reduces the violent behaviour of people and control criminal activities (Ramzy 2015). Henceforth, the Muamalat aspect of religiosity in this research convinced the researchers to find religiosity to explain the low rate of delinquent behaviour of adolescents in Shah Alam.

From the discussion above on religiosity and antisocial behaviour, it is clear that there is an inverse relationship between religiosity and delinquent behaviour. This research, therefore, determines that the inverse relationship between religiosity and delinquent behaviour among students in Shah Alam might have contributed to the low crime rate.

As the limitation of the study, this research considered only the Muslim school students in Shah Alam to explore the relationship between religiosity and delinquency. This research should extend to other states in Malaysia, mainly the estate where the delinquency rate among students is higher than others, to obtain a more detailed correlation report. Further, this research depends only on the crime index data publicly available. Hence, it should be updated with the latest crime rate accessible to authorities to determine the accuracy. Nevertheless, the different methodologies such as correlational or experimental analysis can test the hypotheses suggested in this study. 
Further, this research also considered only socio-economic reasons and religiosity as influencing motivations for delinquent behaviour. However, this research suggests considering possible other factors contributing to delinquency, such as the safe city programme initiated by the Ministry of Home Affairs Malaysia.

\section{Conclusions}

This research investigated the association between religiosity and delinquent behaviour among adolescents. As the efforts of governments and civil society organisations did not give expected results to control the growing trend of violence and delinquent behaviour among school students, researchers are interested in introducing religiosity as an alternative to face this phenomenon.

Researchers noticed a low crime rate among school students in Shah Alam compared to other parts of Malaysia. However, Shah Alam has high potential for criminal activities due to socio-economic reasons. This situation made the researchers ask whether religiosity controls students' delinquent behaviour in Shah Alam.

This research attempted to identify the level of religiosity among school students in Shah Alam to answer this question. For this purpose, this research used a survey instrument prepared based on the Muslim Religiosity and Personality Inventory (MRPI). This instrument collected the data from students in Shah Alam aged between 13-14 from four perspectives, namely Aqidah or worldview, Ahlaq or ethics, Ibadat or rituals, and Muamalat or social relationship. Descriptive data analysis of this survey found a moderate level of religiosity among students from all these perspectives.

The possible relationship between religiosity and delinquent behaviour among students was studied in this research using the qualitative research method. Semi-structured interviews were conducted to collect the data from the school counsellor and discipline teachers. The collected data were transcribed, coded, and analysed. From this data analysis, this research found a significant relationship between religiosity and delinquent behaviour.

As previous studies identified the influence of socio-economic reasons such as parents' income, parents' education level, urbanisation, parents' social status, etc., on delinquent behaviour of school students, this research excluded the impact of these reasons on the crime rate of students in Shah Alam.

Hence, this research found an inverse relationship between religiosity and delinquent behaviour and supported the social control theorists and addiction scientists finding the role of religion in adjusting human behaviour. Hence, this research perceives that the religiosity among students in Shah Alam might have contributed to controlling the crime rate.

This finding encouraged the researchers to propose religiosity as an effective mechanism to control delinquency among school students. Further, this research recommends student counsellors and discipline teachers effectively use religiosity to minimise school violence. For this, they could frequently remind students to remember God, retributions, and religious responsibility towards others.

Author Contributions: Conceptualization, M.I.R. and P.M.M.I.; methodology, M.I.R.; software, Z.H.; formal analysis, Z.H.; writing-original draft preparation and editing, M.I.R. All authors have read and agreed to the published version of the manuscript.

Funding: This research received no external funding.

Institutional Review Board Statement: Not applicable.

Informed Consent Statement: Informed consent was obtained from all subjects involved in the study.

Data Availability Statement: The data presented in this study are available on request from the first author, e-mail: ismathramzy@um.edu.my.

Conflicts of Interest: The authors declare no conflict of interest. 


\section{References}

Abou-Youssef, Mariam, Wael Kortam, Ehab Abou-Aish, and Noha El-Bassiouny. 2011. Measuring Islamic-driven buyer behavioral implications: A proposed market-minded religiosity scale. Journal of American Science 7: 728-41.

Ahmed, Sameera. 2009. Religiosity and presence of character strengths in American Muslim youth. Journal of Muslim Mental Health 4: 104-23. [CrossRef]

Aisyah, Muniatly. 2016. The Influence of Religious Behavior on Consumers'intention to Purchase Halal-Labeled Products. Business and Entrepreneurial Review 14: 15-32. [CrossRef]

Akiba, Motoko, Gerald K. LeTendre, David P. Baker, and Brian Goesling. 2002. Student victimisation: National and school system effects on school violence in 37 nations. American Educational Research Journal 39: 829-53. [CrossRef]

Alam, Syed Shah, Rohani Mohd, and Badrul Hisham. 2011. Is religiosity an important determinant on Muslim consumer behaviour in Malaysia? Journal of Islamic Marketing 2: 83-96. [CrossRef]

Al-Ammar, Fawziah, Ismaiel Hamid Ahmed, and Mohamad Sahari Nordin. 2012. Moral character of Muslim personality: Scale validation. Journal of Education and Practice 3: 118-28.

Alghamdi, Abdullah. 2006. Role of Islamic Educational Values in Developing Emotional Intelligence Skills. Master's thesis, The University of Montana, Missoula, MT, USA. Available online: https://scholarworks.umt.edu/cgi/viewcontent.cgi?article=6015 \&context=etd (accessed on 20 August 2021).

Ali, Afzaal, Adnan Ali, and Mehkar Sherwani. 2017. Shaping halal into a brand? Factors affecting consumers' halal brand purchase intention. Journal of International Food E Agribusiness Marketing 29: 234-59.

Al-Khalifah, Abdullah H. M. 1994. Religiosity in Islam as a protective mechanism against criminal temptation. American Journal of Islamic Social Sciences 11: 1-14. [CrossRef]

Amini, Fatemeh, Parvaneh Doodman, Ali Edalati, Zhila Abbasi, and Mohd Redzuan. 2014. A study on the relationship between religiosity and forgiveness among students. Applied Science Reports 5: 131-34.

Aute, Dorothy Anyango, Moses Wesang'ula Poipoi, and Okaya Edward Khasakhala. 2020. Family Socioeconomic Status and Deviant Behaviour Among Secondary School Students in Homabay County, Kenya. Science Journal of Education 8: 14-21. [CrossRef]

Benbenishty, Rami, and Ron Astor. 2008. School violence in an international context. International Journal 60: 69-79. Available online: http:/ / www.ijvs.org/files/Revue-07/04.-Benbenishty-Ijvs-7.pdf (accessed on 4 April 2021).

Bernama. 2014. Violent Culture Seeping into Schools. Bernama. Available online: http://www.freemalaysiatoday.com/category/ nation/2014/02/24/lee-violent-culture-seeping-into-schools/ (accessed on 10 February 2021).

Berti, Chiara, and Monica Pivetti. 2019. Childhood economic disadvantage and antisocial behavior: Intervening factors and pathways. Children and Youth Services Review 97: 120-26. [CrossRef]

Borg, Walter, Joycem Gall, and Meredith Gall. 1979. Educational Research: An Introduction, 3rd ed. New York: Longman.

Brain. 2013. Malaysia: Among the Most Dangerous Countries in the World? Hornbill Unleashed. Available online: https:// hornbillunleashed.wordpress.com/2013/11/24/53436/ (accessed on 28 May 2021).

Browman, Alexander S., Mesmin Destin, Melissa S. Kearney, and Phillip B. Levine. 2019. How economic inequality shapes mobility expectations and behaviour in disadvantaged youth. Nature Human Behaviour 3: 214-20. [CrossRef]

Card, Noel, Stucky Brian, Sawalani Gita, and Little Todd. 2008. Direct and indirect aggression during childhood and adolescence: A meta-analytic review of gender differences, intercorrelations, and relations to mala adjustment. Child Development 79: 1185-229. [CrossRef]

Cassidy, Simon. 2004. Learning styles: An overview of theories, models, and measures. Educational Psychology 24: 419-44. [CrossRef]

Chalfin, Aaron, and Monica Deza. 2019. The intergenerational effects of education on delinquency. Journal of Economic Behavior $\mathcal{E}$ Organization 159: 553-71.

Christians, Clifford G., and James William Carey. 1989. The logic and aims of qualitative research. Research Methods in Mass Communication 2: 354-74.

Christina Low. 2012. Islamic city set to take shape in Shah Alam. The Star. Available online: https://www.thestar.com.my/news/ community/2012/05/14/islamic-city-set-to-take-shape-in-shah-alam (accessed on 10 February 2021).

Cohen, Louis, Lawrence Manion, and Keith Morrison. 2000. Research Methods in Education British Library Cataloguing in Publication Data. Abingdon: The British Library.

Daly, Kathleen. 1989. Neither conflict nor labeling nor paternalism will suffice: Intersections of race, ethnicity, gender, and family in criminal court decisions. Crime E Delinquency 35: 136-68.

Dastagir, Gulam, and Mohammad Ismath Ramzy. 2019. Understanding “The Others": Buddhist-Islamic Dialogue for Peace with Particular Reference to 'Moderation'. Al-Shajarah: Journal of the International Institute of Islamic Thought and Civilization (ISTAC) 24: 25-47.

Davidson, Christiana. 2009. Transcription: Imperatives for qualitative research. International Journal of Qualitative Methods 8: 35-52. [CrossRef]

Department of Statistics Malaysia. 2016. Children Statistic Malaysia 2016; Putrajaya: Department of Statistics Malaysia. Available online: https://www.dosm.gov.my/v1/index.php?r=column/cthemeByCat\&cat=333\&bul_id=NVYwaEtwM2 1MempVbWpBZFpxOFZHZz09\&menu_id=U3VPMldoYUxzVzFaYmNkWXZteGduZz09 (accessed on 20 August 2021). 
Department of Statistics Malaysia. 2019. Press Release Children Statistics Malaysia 2019. Putrajaya: Department of Statistics Malaysia. Available online: https://www.dosm.gov.my/v1/index.php?r=column/pdfPrev\&id=c3I4eitkb1RZTIMvUjNLZVRBMExVQT09 (accessed on 20 August 2021).

Education Destination Malaysia. 2019. What you need to know about bullying in school. Education Destination Malaysia Blog. Available online: https:/ / educationdestinationmalaysia.com/blogs/what-you-need-to-know-about-bullying-in-schools (accessed on 6 February 2021).

El-Menouar, Yasemin. 2014. The five dimensions of Muslim religiosity. Results of an empirical study. Methods, Data, Analyses 8: 53-78.

El Sen, Teoh. 2014. Students Involved in Violent Crime and Gangsterism on the Rise. Astro Awani. Available online: http:/ / english. astroawani.com/malaysia-news/students-involved-violent-crime-and-gangsterism-rise-32766 (accessed on 1 April 2021).

Epic Teachers. 2013. What is Merit-demerit system. Epic Teachers Blog. Available online: http:/ / epicteachers.blogspot.com/2013/03/ what-is-merit-demerit-system.html (accessed on 24 August 2021).

Ferdoos, Ahmad, and Ahmad Ashiq. 2015. Impact of urbanisation on juvenile delinquency: A study of Muzaffarabad jail. International Journal of Criminology and Sociological Theory 8: 1-14.

Fisher, Murray, and Andrea Marshall. 2009. Understanding descriptive statistics. Australian Critical Care 22: 93-97. [CrossRef] [PubMed]

Fraenkel, Jack, Wallen Norman, and Hyun Helen. 2012. How to Design and Evaluate Research in Education. Johnproyer.com. Available online: http://www.johnlpryor.com/JP_Digital_Portfolio/EDU_7901_files/EDU\%207901\%20Data\%20Definitions.pdf (accessed on 29 September 2021).

Gibbs, Graham R. 2007. Thematic coding and categorising. Analysing Qualitative Data 703: 38-56.

Gorsuch, Richard. 1983. Factor Analysis. Hillsdale: John Wiley \& Sons Inc., vol. 2.

Güneş, Tacettin. 2003. The Relationship between Religiosity and Crime: A Case Study on University Students in Turkey. Unpublished Ph.D. thesis, Middle Eastern Technical University, Ankara, Turkey; p. 43. Available online: https://etd.lib.metu.edu.tr/upload/ 418368/index.pdf (accessed on 16 August 2021).

Hair, Joe F., Page Michaeal, and Niek Brunsveld. 2019. Essentials of Business Research Methods. Abingdon-on-Thames: Routledge.

Hanif, Hanafi Hadi, and Shariff Nadiah Syariani Md. 2020. Fear of crime: Crime perception and coping strategy in Shah Alam. International Journal of Medical Toxicology and Legal Medicine 23: 120-24. [CrossRef]

Hashim, H., M. Sadek, and Mohd Wan. 2018. The spatial distribution of "hotspot schools" and the relationship with crime pattern in Mukim Petaling and Klang. In IOP Conference Series: Earth and Environmental Science. Bristol: IOP Publishing, vol. 169, p. 012109.

Herrera, Veronica, and Laura Ann McCloskey. 2001. Gender differences in the risk for delinquency among youth exposed to family violence. Child Abuse \& Neglect 25: 1037-51.

Hoffstaedter, Graham. 2011. Modern Muslim Identities: Negotiating Religion and Ethnicity in Malaysia. Copenhagen: NIAS Press.

Ismail, Nik Ahmad Hisham, and Mustafa Tekke. 2015. Development and initial validation of integrative Islamic personality inventory. Advances in Environmental Biology 9: 163-71.

Isralowitz, Richard, and Alexander Reznik. 2015. Impact of religious education and religiosity on adolescent alcohol use and risk-taking behavior. Religious Education 110: 303-10. [CrossRef]

Jansen, Anja M., Ellen Giebels, Thomas J. L. van Rompay, and Marianne Junger. 2018. The influence of the presentation of camera surveillance on cheating and pro-social behavior. Frontiers in Psychology 9: 1937. [CrossRef]

Kamaruddin, Muhammad Iqmal Hisham, and Sofiah MdAuzair. 2019. Integrated Islamic financial accountability model for Islamic social enterprise (ISE). The Journal of Muamalat and Islamic Finance Research 16: 17-36. [CrossRef]

Kim, Jinho. 2021. Gender differences in the educational penalty of delinquent behavior: Evidence from an analysis of siblings. Journal of Quantitative Criminology 37: 179-216. [CrossRef]

Krauss, Steven Eric, Azimi Hamzah, and Fazila Idris. 2007. Adaptation of a Muslim religiosity scale for use with four different faith communities in Malaysia. Review of Religious Research 49: 147-64.

Krauss, Steven, Al Haj Hamzah, Turiman Suandi, Sidek Mohd Noah, Khairul Anwar Mastor, Rumaya Juhari, and Manap. 2005. The Muslim religiosity-personality measurement inventory (MRPI)'s religiosity measurement model: Towards filling the gaps in religiosity research on Muslims. Pertanika Journal of Social Sciences \& Humanities 13: 131-45.

Kunin, Seth. 2003. Religion: The Modern Theories. Boca Raton: Taylor \& Francis US.

Malaysian Education Blueprint. 2015. Blueprint 2015-2025 (Higher Education); Putrajaya: Ministry of Education. Available online: https:/ / www.um.edu.my/docs/um-magazine/4-executive-summary-pppm-2015-2025.pdf (accessed on 10 February 2021).

McDermott, Robert J., and Paul Sarvela. 1999. Methods and strategies for sampling. In Health Education Evaluation and Measurement: A Practitioner's Perspective. Dubuque: William C Brown Pub, pp. 264-89.

Marshall, Douglas. 2002. Behavior, belonging, and belief: A theory of ritual practice. Sociological Theory 20: 360-80. [CrossRef]

Moustakas, Clark. 1994. Phenomenological Research Methods. Thousand Oaks: Sage Publications.

Moffitt, Terrei, Avshalom Caspi, Micheal Rutter, and Silva Phil. 2001. Sex Differences in Antisocial Behaviour: Conduct Disorder, Delinquency and Violence in the Dunedin Longitudinal Study. Cambridge: Cambridge University Press.

Muhammad, Abul Qassim. 1983. The Ethics of Al-Ghazali: A Composite Ethics in Islam. Selangor: National University of Malaysia.

Nabilah, Hamudin. 2015. Shah Alam crime index shows drop in first four months of 2015. The Sun Daily. Available online: http: / / www.thesundaily.my/news/1416772 (accessed on 4 April 2021).

Neto, Fellix. 2007. Forgiveness, personality and gratitude. Personality and Individual Differences 43: 2313-23. [CrossRef] 
Newberg, Andrew. 2016. How God changes your brain: An introduction to Jewish neurotheology. CCAR Journal: The Reform Jewish Quarterly, Winter 19: 18-25.

Newberg, Andrew, and Mark Robbert Waldman. 2013. Words Can Change Your Brain: 12 Conversation Strategies to Build Trust, Resolve Conflict, and Increase Intimacy. London: Penguin Books Ltd.

Newberg, Andrew B., Nancy A. Wintering, David B. Yaden, Mark Robbert, Waldman, Janet Reddin, and Abass Alavi. 2015. A case series study of the neurophysiological effects of altered states of mind during intense Islamic prayer. Journal of Physiology-Paris 109: 214-20. [CrossRef]

New Strait Time. 2019. School Bully: Home Remedy. New Straits Times. Available online: Https://Www.Nst.Com.My/Opinion/ Leaders/2019/01/450202/School-Bully-Home-Remedy (accessed on 21 February 2021).

Nunnally, Jum. 1978. Psychometric Theory. New York: McGraw-Hill.

Nye, Ivan, Short James, and Olson Virgil. 1958. Socio-economic status and delinquent behavior. American Journal of Sociology 63: 381-89. [CrossRef]

Oshako, Toshio. 1997. Tackling school violence worldwide: A comparative perspective of basic issues and challenges. In Violence at School: Global Isues and Inerventions. Paris: UNESCO/IBE.

Othman, Nooraini. 2011. Exploring the ummatic personality dimensions from the psycho-spiritual paradigm. International Journal of Psychological Studies 3: 37-42. Available online: www.ccsenet.org/journal/index.php/ijps/article/view/13335/9202 (accessed on 21 April 2021).

Patton, Michael Quinn. 1999. Enhancing the quality and credibility of qualitative analysis. Health Services Research 34, Pt 2: 1189.

Payne, Reed, Bergin Allen, Bielema Kimberly, and Jenkins Paul. 1991. Review of religion and mental health: Prevention and the enhancement of psychosocial functioning. Prevention in Human Services 9: 11-40. [CrossRef]

Pitts, John. 2015. Youth Crime and Youth Justice. Youth E Policy 114: 31-42.

Ramzy, Mohammad Ismath, Azni Yati, and Faisal Mohammd. 2020. Universal Aspects of Islamic Religious Ethics and Muslim Extremism. Journal of Dharma 45: 437-52.

Ramzy, Mohammad Ismath. 2015. Training in Islamic Rituals: A Solution to Muslim Extremism. KATHA-The Official Journal of the Centre for Civilisational Dialogue 11: 75-90.

Rashid, Mohd Fadzil Abdul, and Ishak Ab Ghani. 2011. The Importance of Internal Migration in Urban Planning Process: The Case Study of Klang Valley Region. International Journal of Social Planning and Development 1: 1-12.

Rashidiyaan, Somaye, Amrollah Amini, Mohammad Mehdi Mojahedi, and Ali Safdari. 2018. Modelling an Interest Free Economy Through Overlapping Generation Model (OLG). Journal of Economics and Modeling 9: 91-129.

Roid, Gale, and Thomas Haladyna. 1982. A Technology for Test-Item Writing. Cambridge: Academic Press.

Russell, James, and Graldine Pratt. 1980. A description of the affective quality attributed to environments. Journal of Personality and Social Psychology 38: 311-22. [CrossRef]

Sanchez, Zila van der Meer, and Solange Aparecida Nappo. 2008. Religious intervention and recovery from drug addiction. Revista de Saude Publica 42: 265-72. [CrossRef] [PubMed]

Santhana, Dass, and Ananthan Rueben. 2019. Crime Trends and Patterns in Malaysia. Kyoto Review of Southeast Asia. Available online: https: / kyotoreview.org/trendsetters/crime-trends-and-patterns-in-malaysia/ (accessed on 12 February 2021).

Small, Mario Luis. 2011. How to conduct a mixed-methods study: Recent trends in a rapidly growing literature. Annual Review of Sociology 37: 57-86. [CrossRef]

Soh, Mazlan, and Bin Che. 2012. Crime and urbanisation: Revisited Malaysian case. Procedia-Social and Behavioral Sciences 42: 291-99. [CrossRef]

Sonnenberg, Bettina. 2014. Social Integration and Social Involvement from a Societal and Individual Perspective. In Dependencies and Mechanisms of Unemployment and Social Involvement. Wiesbaden: Springer VS, pp. 25-58.

Suhail, Kuasar, and Haroon Rashid Chaudhry. 2004. Predictors of subjective wellbeing in an Eastern Muslim culture. Journal of Social and Clinical Psychology 23: 359-76. [CrossRef]

Synder, James, and Gerald Patterson. 1987. Family interaction and delinquent behaviour. In Handbook of Juvenile Delinquency. Nueva York: Wiley, pp. 216-43.

The Star. 2014. Tackling school violence. The Star Online. Available online: http:/ / www.thestar.com.my/opinion/letters/2014/08/11 /tackling-school-violence/ (accessed on 5 March 2021).

The Department of Statistics. 2016. Press Release: Children Statistics, Malaysia 2016. Putrajaya: The Office of Chief Statistician Malaysia, Department of Statistics. Available online: https:/ / www.dosm.gov.my/v1/index.php?r=column/pdfPrev\&id=NVYwaEtwM2 1MempVbWpBZFpxOFZHZz09 (accessed on 12 August 2021).

Tiliouine, Habib, Cummins, and Melanie Davern. 2009. Islamic religiosity, subjective wellbeing, and health. Mental Health, Religion $\mathcal{E}$ Culture 12: 55-74.

Uba, Ikechukwu, Siti Nor Yaacob, Mansor Abu Talib, Rohani Abdullah, and Sakineh Mofrad. 2014. Association among peer substance use, religiosity and substance abuse in high school students. Pakistan Journal of Social Sciences 11: 1-6. Available online: http:/ / psasir.upm.edu.my/id/eprint/36575/1/Association\%20among\%20peer\%20substance\%20use.pdf (accessed on 28 May 2021).

UNESCO. 2019. Behind the Numbers: Ending School Violence and Bullying. Paris: UNESCO. Available online: https://www.unicef.org/ media/66496/ file/Behind-the-Numbers.pdf (accessed on 8 May 2021). 
UNICEF. 2013. The Malaysian Juvenile Justice System: A Study of Mechanisms for Handling Children in Conflict with the Law. Kuala Lumpur: Ministry of Women, Family and Community Development and UNICEF Malaysia. Available online: http://www. iccwtnispcanarc.org/upload/pdf/1672867150Malaysian\%20Juvenile\%20Justice\%20System.pdf (accessed on 12 August 2021).

Usman, Hardius. 2015. Islamic religiosity scale, and its applied on the relationship between religiosity and selection of Islamic bank. East Asian Journal of Business Economics (EAJBE) 3: 1-13.

Vaismoradi, Mojtaba, and Sherrill Snelgrove. 2019. Theme in qualitative content analysis and thematic analysis. Forum Qualitative Sozialforschung/Forum: Qualitative Social Research 20: 1-14. Available online: https://www.qualitative-research.net/index.php/ fqs/article/view/3376/4471 (accessed on 12 April 2021).

Vierra, Andrea, and Judith Pollock. 1992. Reading Education Research. Scottsdale: Gorsuch Sewishirch.

Wahab, Azna Abdul, Siti Rasidah Md Sakip, and Halmi Zainol. 2018. An assessment of CPTED principles in relation to bullying behaviour. Advances in Applied Sociology 8: 25-48. [CrossRef]

Weber, Max, and Stephen Kalberg. 2013. The Protestant Ethic and the Spirit of Capitalism. Abingdon-on-Thames: Routledge. Available online: https://scholar.princeton.edu/sites/default/files/tpavone/files/weberthe_protestant_ethic_and_the_spirit_of_ capitalism_summary.pdf (accessed on 8 May 2021).

WHO. 2020. Youth Violence. WHO. Available online: https://www.who.int/news-room/fact-sheets/detail/youth-violence (accessed on 12 April 2021).

Wiersma, William, and Stephen Jurs. 2000. Research Methods in Education: An Introduction. Boston: Allyn.

Wright, Kevin, and Karen Wright. 1992. Family Life and Delinquency and Crime: A Policy-Makers Guide to the Literature; Unpublished manuscript. Washington: Office of Juvenile Justice and Delinquency Prevention. Available online: https://www.ncjrs.gov/ pdffiles1/Digitization/140517NCJRS.pdf (accessed on 12 April 2021).

Zhang, Xianquan. 2016. The trends, promises and challenges of urbanisation in the world. Habitat International 54: 241-52. [CrossRef] 